\title{
ВОЗМОЖНОСТИ АДАПТАЦИИ ДЕТЕЙ МИГРАНТОВ В ШКОЛАХ МОСКВЫ И ПОДМОСКОВЬЯ
}

\author{
ЕКАТЕРИНА ДЕМИНЦЕВА, ДАРЬЯ ЗЕЛЕНОВА, \\ ЕЛИЗАВЕТА КОСМИДИС, ДМИТРИЙ ОПАРИН
}

\begin{abstract}
В статье представлены результаты исследования, направленного на изучение адаптаџии детей мигрантов в школах Москвы и Подмосковья. Анализируется сложности, возникаюшие у семей мигрантов при записи ребенка в школь. Проводится анализ ситуации попадания ребенка из семьи мигрантов в иколь со «сложным социальным контекстом». Авторы приходят к выводу, что для учителей важную роль в понимании, кто такой «ученик-мигрант», является этническое происхождение детей, а не их гражданство. Основной проблемой адаптаџии детей мигрантов $в$ школах и сами дети, и учителя школ называют незнание русского языка в первый год обучения. Отсутствие программ, направленных на обучение русскому как иностранному, а также курсов подготовки учителей для работы с многоэтничными классами затрудняют быструю ассимиляцию детей мигрантов. Под влиянием миграционных потоков и появления все большего числа детей мигрантов в некоторых школах происходит изменение самого икольного пространства. Внеклассные практики становятся более разнообразными и зачастую этнически ориентированными. Этнизаџия школьного пространства является отражением и продолжением этнизации городской среды.
\end{abstract}

Ключевые слова: дети мигрантов, икольl, ассимиляция, адаптаџия, этнизаџия.

В последние годы в российском обществе все чаще говорят о проблеме присутствия в школах детей мигрантов [Зайончковская и др. 2014; Троицкий 2017], однако исследований, направленных на понимание реальной ситуации, существует крайне мало [Александров и др. 2011; 2012; Александров и др. 2015; Омельченко и др. 2010; Сабирова, Андреева 2014; Солдатова 2014]. Ситуация единичных исследований, посвященных этой теме, объясняется как сложностью «вхождения» в школы, требующего согласования с государственными институтами, так и отсутствием артикуляции данной темы на уровне департаментов образования и других государственных структур. В открытом доступе нет статистики, показывающей, какое число детей мигрантов учится в школах России, нет отчетов государственных структур о том, какие образовательные и внеклассные программы направлены на адаптацию детей мигрантов.

ЕКАТЕРИНА БОРИСОВНА ДЕМИНЦЕВА (edemintseva@hse.ru), НАЦИОНАЛЬНЫЙ ИССЛЕДОВАТЕЛЬСКИЙ УНИВЕРСИТЕТ «ВЫСШАЯ ШКОЛА ЭКОНОМИКИ», РОССИЯ.

ДАРЬЯ АЛЕКСАНДРОВНА ЗЕЛЕНОВА (d.zelenova@gmail.com), НАЦИОНАЛЬНЫЙ ИССЛЕДОВАТЕЛЬСКИЙ УНИВЕРСИТЕТ «ВЫСШАЯ ШКОЛА ЭКОНОМИКИ», РОССИЯ.

ЕЛИЗАВЕТА АЛЕКСЕЕВНА КОСМИДИС (kosmidislisa@gmail.com), НАЦИОНАЛЬНЫЙ ИССЛЕДОВАТЕЛЬСКИЙ УНИВЕРСИТЕТ «ВЫСШАЯ ШКОЛА ЭКОНОМИКИ», РОССИЯ.

ДМИТРИЙ АНАТОЛЬЕВИЧ ОПАРИН (dimaoparin@hotmail.com), НАЦИОНАЛЬНЫЙ ИССЛЕДОВАТЕЛЬСКИЙ УНИВЕРСИТЕТ «ВЫСШАЯ ШКОЛА ЭКОНОМИКИ», РОССИЯ.

СТАТЬЯ НАПИСАНА ПО ИТОГАМ ПРОЕКТА ПРОГРАММЫ ФУНДАМЕНТАЛЬНЫХ ИССЛЕДОВАНИЙ НАЦИОНАЛЬНОГО ИССЛЕДОВАТЕЛЬСКОГО ПРОЕКТА ВЫСШЕЙ ШКОЛЫ ЭКОНОМИКИ НИУ ВШЭ 2017 ГОДА.

СТАТЬЯ ПОСТУПИЛА В РЕДАКЦИЮ В ИЮНЕ 2017 Г. 
Эта тема остается маргинальной на разных уровнях: и в научных исследованиях, и в общественных и государственных дебатах. Основными «поставщиками» информации о «мигрантских школах» и «классах, заполненных мигрантами» остаются российские средства массовой информации ${ }^{1}$, часто передающие существующие в обществе стереотипы, а не реальную ситуацию.

Однако сегодня возрастает потребность в понимании реальной ситуации: как дети мигрантов, обучающиеся в школах России, распределяются между учебными заведениями, и насколько затруднена их адаптация в школьном коллективе. Во-первых, увеличилось количество семей мигрантов, привозящих в Россию детей [Деминцева, Пешкова 2014; Флоринская и др. 2015]. Во-вторых, вокруг темы присутствия детей мигрантов в школах растет число мифов, создаваемых как СМИ, так и родителями и «местных» детей, и мигрантов. Родители «местных» опасаются большого числа не говорящих по-русски детей в классах и соответственно более низкого уровня образования. Родители детей мигрантов с опасением относятся к коммуникации с государственными школами.

Александровым и коллегами [2015] подсчитано, что в школах исследуемых ими городов и регионов (Москва, Московская область, Санкт-Петербург, Ленинградская область, Томск, Псков, несколько небольших городов в других областях России, N=6992, 162 школы) «русские дети составляют от 85 до 93\% учащихся, и только от 7 до 16\% приходится на представителей других этнических групп... Наибольшее число представителей других этносов живет в Московской области (16,2\%)» [Александров и др. 2105: 179]. Дети, чьи родители родились за пределами России и относятся к представителям иноэтничных групп, не составляют большинства и даже половины от всех учащихся в Подмосковных школах и в других городах и регионах России.

Наше исследование было проведено в городе и регионе, обозначенных исследователями как те, в школах которых больше всего иноэтничных детей [Александров и др. 2105]. Объектом нашего внимания были дети, имевшие опыт миграции, те, кто приехал в Россию из других стран в школьном возрасте. В отличие от коллег, проводивших исследования в разных по социальному составу и результатам успеваемости школах, наше исследование было сконцентрировано только в школах со «сложным социальным контекстом». Как определили наши коллеги из Института образования НИУ ВШЭ [Фрумин и др. 2012], именно в этих школах учатся дети, чьим языком не является русский. Таким образом, мы изначально вошли в школы, в которых учатся преимущественно дети из семей с низким социальным статусом, и результаты успеваемости в которых ниже, чем в других школах города и области.

Целью нашего исследования было понять, почему дети мигрантов попадают именно в такие школы, как происходит в этих школах адаптация детей, как складываются их

\footnotetext{
${ }^{1}$ Балабас Е. (2015). Число детей мигрантов в столичных школах доходит до $60 \%$. Но адаптируются они с трудом // Московский комсомолец. 14 декабря. URL: http://www.mk.ru/social/2015/12/14/chislo-deteymigrantov-v-stolichnykh-shkolakh-dokhodit-do-60.html (дата обращения: 10.06.2017). Ващенко В. (2016). Я пошель впервые в школь. Учителя не знают, как учить детей мигрантов в школах // Газета.ру. 9 сентября. URL: https:/www.gazeta.ru/social/2016/09/09/10184939.shtml (дата обращения: 10.06.2017).
} 
отношения с одноклассниками и учителями и можно ли сегодня говорить, что школьное пространство меняется в связи с появлением в нем детей мигрантов.

В странах Европы и Америки существуют обширные исследования, посвященные детям мигрантов, обучающихся в школах разных стран. Исследования, направленные на изучение адаптации детей мигрантов, анализируют образовательные и социальные барьеры, с которыми детям иностранцев приходится сталкиваться в школе. Ученые отмечают, что детям мигрантов, в особенности плохо владеющим или не владеющим вовсе языком принимающего общества, необходимы дополнительные занятия, в которых не испытывают необходимости «местные» дети [Vernez, Abrahamse 1996; Christensen, Stanat 2007; OECD 2015]. Также эти дети сталкиваются со специфическими для мигрантов проблемами, которые могут мешать их адаптации в учебном заведении и коммуникации со сверстниками. К таким проблемам можно отнести высокую мобильность их семей (семьи мигрантов чаще, чем семьи «местных», переезжают с места на место); они в большей степени подвержены эмоциональному стрессу при попадании в школу, так как оказываются в новых для себя условиях социальных и этических норм; многие из них вынуждены расстаться с частью семьи, что также является большой нагрузкой на психологическое состояние ребенка [Rumbaut 1995; Alba, Holdaway 2013].

По мнению исследователей, именно знание языка принимающего общества является наиболее важным фактором для более легкой ассимиляции и ключевым фактором успеха в обучении детей мигрантов в школе [Rumbaut 1997; Genesee et al. 2006; Christensen, Stanat 2007]. Румбо [Rumbaut 1997] указывает на то, что чем в более раннем возрасте ребенок приезжает в страну, тем быстрее он овладевает языком страны. Он обозначил период от шести лет до раннего подросткового возраста, когда ребенок без особых усилий может овладеть языком. При этом им подчеркивается, что школьная среда в этом случае играет особую роль. Ребенок легче овладевает языком, находясь в школьном коллективе, где он также знакомится с нормами жизни и культурой принимающего общества.

Еще одной важной проблемой адаптации детей является возможный конфликт ребенка из мигрантской семьи со своими родителями, в особенности, если семья придерживается других правил и ограничений, нежели принимающее общество [Olsen 1988; Rumbaut 1994; Crul, Holdaway 2009]. Эта проблема распространяется в большей степени на учеников средней школы, когда дети входят в подростковый возраст. Так, девочки из мусульманских семей в американском или европейском обществе могут испытывать сильное давление со стороны своих мигрантских семей [Rumbaut 1994; LacosteDujardin 1992]. Эта ситуация может приводить к напряженности между девочкамимигрантками и их родителями, поскольку они пытаются интегрироваться в культуру принимающего общества, которая противоречит традиционному взгляду на роль женщин их семей.

Ученые, проводившие исследования в США, утверждают, что дети мигрантов часто встречаются с расовыми предрассудками и дискриминацией [James 1997; Rumbaut 1997; Karsten 2006]. Попадая в школу, в особенности без знания языка, ребенок сталкивается с агрессией или же плохим отношением со стороны одноклассников. Однако расовая дискриминация может не ограничиваться первыми годами жизни в стране. Восприятие 
ребенком-мигрантом и даже выходцем из мигрантской среды дискриминации может быть различным в зависимости от продолжительности пребывания в стране, но не исчезает полностью [Gil et al. 1994; Crul, Vermeule 2003; Alba, Holdaway 2013]. Исследователи даже предполагают, что второе поколение может чувствовать себя еще более дискриминированным, поскольку его представители, уже граждане страны, имеют более высокие ожидания и стремления [Rogler et al. 1991; Crul et al. 2012]. Эту же ситуацию можно наблюдать, например, во Франции, где дети мигрантов, родившиеся у себя в стране, более восприимчивы к любого рода расовой дискриминации по отношению к ним [Lapeyronnie 2008]. К тому же многие исследования показали, что дети и внуки иммигрантов сталкиваются с иными и не менее серьезными проблемами, чем мигранты в первом поколении, так как миграция не являлась их решением, и они не были заранее готовы к неминуемым социальным барьерам и дискриминации [Alba, Silberman 2009].

Первое большое исследование о детях мигрантов в школах России было проведено Д. Александровым и его коллегами из Высшей школы экономики в Санкт-Петербурге [Александров и др. 2011; 2012]. В нем доказано, что распределение детей по школам определяется их социальным положением, а не этническим происхождением. Мигранты чаще всего попадают в школы, где учатся дети семей с невысоким социальным статусом. Это же подтверждают коллеги из Института образования НИУ ВШЭ, обследовавшие школы со «сложным социальным контекстом» в нескольких областях России [Фрумин и др. 2012]. В исследовании было доказано, что в такие школы чаще всего попадают дети, для которых русский язык не является родным.

Исследователи увидели, что дети мигрантов учатся не хуже, чем их местные сверстники, а их образовательные планы на жизнь и образовательные стратегии не отличаются от планов других учеников [Александров и др. 2012]. Также исследования показывают, что дети мигрантов не сталкиваются с проблемами ксенофобии и расизма в школах [Александров и др. 2012; Сабирова, Андреева 2014]. Дети мигрантов при выборе друзей не ориентируются на их этническое происхождение, а подростковая компания способствует приобретению мигрантом необходмых молодежных компетенций/социальных навыков для его включения в локальное территориальное сообщество [Сабирова, Андреева 2014].

В статье мы попытаемся ответить на несколько вопросов. Во-первых, мы анализируем, почему дети мигрантов оказываются именно в этих школах и какие существуют у них барьеры при вхождении в нее. Во-вторых, - с какими проблемами сталкиваются дети внутри школы и как на них реагируют окружающие. В-третьих, - как меняются и меняются ли школы с появлением в них детей мигрантов.

\section{ТЕОРЕТИЧЕСКИЕ РАМКИ ИССЛЕДОВАНИЯ}

Вопросы, связанные с адаптацией мигрантов и их детей в принимающем обществе, были и остаются одними из основных в миграционных исследованиях. Исследователи говорят о двух факторах, влияющих на возможности адаптации мигрантов: индивидуальный (личные характеристики индивида) и внешний (в каких условиях живет мигрант в принимающем 
обществе, и какие оно выстраивает отношения с ним). Существуют две теоретические перспективы понимания процессов адаптации мигрантов [Ainsworth 2013]. Первая, классическая теория ассимиляции говорит о том, что со сменой поколений происходит большее включение выходцев из мигрантской среды в группу большинства. То есть чем дольше семья находится в стране, тем больше вероятность, что ребенок полностью ассимилируется в обществе. Гордон [Gordon 1964] в середине 1960-х годов написал о нескольких этапах ассимиляции, которые проходят мигранты. В его понимании сначала можно говорить о структурной ассимиляции, когда у представителя этнического меньшинства завязываются отношения с принимающим обществом. Затем происходит этническая идентификация с принимающим обществом. И наконец, следует отказ от какихлибо предрассудков со стороны большинства по отношению к меньшинству и отказ от его дискриминации. Уже в 2000-х годах Альба и Ни [Alba, Nee 2003] уточняют, что эта теория верна только в условиях, если речь идет о более или менее однородном в расовом и социальном плане обществе, а также при активном участии в этих процессах гражданских институтов.

В начале 1990-х годов Портес и Жу [Portes, Zhou 1993] представили другую теорию - сегментированной ассимиляции. Они настаивают на важной роли структурных барьеров, которые могут препятствовать ассимиляции детей мигрантов. К таким барьерам можно отнести плохую школу в бедном городском квартале, т.е. те условия, которые ограничивают учащихся в них детей в выборе дальнейшей траектории жизни. И эти барьеры, даже при желании детей мигрантов интегрироваться в принимающее общество, препятствуют им в этом и не позволяют выйти из своей социальной и этнической среды. Более того, те дети, которые оказываются в наиболее неблагоприятных условиях, могут вовсе отказаться от ассимиляции в принимающее общество и создать, например, свою банду «таких же как они». Сегментированная модель ассимиляции фокусируется на выявлении контекста, структурных и культурных факторов, которые или влияют на успешную ассимиляцию, или же определяют ее неудачи.

Еще одна из моделей - адаптации и аккультурации без ассимиляции (accommodation and acculturation without assimilation) или кумулятивной аккультурации (additive acculturation) [Gibson 1988] - говорит об ассимиляции, при которой дети не заменяют одну культуру другой, а дополняют свою новой. Гибсон доказала возможность такой модели ассимиляции на примере детей сикхов в Калифорнии. Она пришла к выводу, что академически успешными зачастую оказываются те дети, которые как осваивают язык и культуру принимающего общества, так и сохраняют крепкие культурные и социальные связи со своим сообществом.

Ориентируясь на эти модели, мы постараемся понять, о какой модели ассимиляции можно сегодня говорить в рассматриваемых нами школах. Нам важно увидеть не только восприятие ребенком из мигрантской среды тех проблем, с которыми он сталкивается, но и тот контекст, в котором эти процессы происходят. 


\section{МЕТОДОЛОГИЯ ИССЛЕДОВАНИЯ}

Нами были выбраны 8 школ в Подмосковье, в которых были проведены 5 фокус-групп с детьми мигрантов и 2 фокус-группы с «местными» детьми. Все фокус-группы проводились с учениками 9-11-х классов. Также во всех 8 школах были проведены интервью с учителями и директорами школ $(\mathrm{N}=34)$.

Что касается московского поля, то мы изменили метод исследования. Нами были проведены 21 интервью с детьми мигрантов, которые учатся в московских школах, а также 30 интервью с учителями московских школ, в которых присутствует значительное число детей мигрантов.

Под детьми мигрантов в данном исследовании мы понимали тех детей, которые имели опыт переезда из другой страны вне зависимости от этнического происхождения и социального статуса. Все эти дети были учащимися только школ «со сложным социальным контекстом», в которых мы проводили исследование. У детей могло быть как российское гражданство, так и гражданство своей страны. Мы не принимали во внимание этот статус (гражданство), так как некоторые семьи могли получить российское гражданство по облегченной схеме и при этом жить на территории другой страны.

При отборе школ в Подмосковье мы исходили из результатов исследований Института образования НИУ ВШЭ. В 2011-2012 гг. Институтом образования было доказано, что в школах с более низкими результатами ЕГЭ характерна концентрация детей из семей с низким социальным статусом, а также детей, чей язык не является русским [Фрумин и др. 2012]. Вторым важным для отбора информантов показателем стали результаты исследований того же института, в которых проанализировано влияние территориального фактора на результативность образовательных учреждений [Фрумин и др. 2012]. Так, поселение, в котором расположена школа, может рассматриваться для нее в качестве источника ресурсов: в городах или районах города с низко статусным населением (вокруг закрытых заводов, в старых поселках без производств) большая вероятность наличия социальных проблем и соответственно вероятность попадания в школы детей с низким социальным статусом велика. Поэтому мы ориентировались на школы, расположенные в старых подмосковных городах и рядом с закрытыми предприятиями.

Также результаты исследований коллег из Института образования указывают на то, что возможна ситуация, когда в социально смешанном районе города при наличии нескольких школ одни учебные заведения являются «престижными» (в них отдают детей из семей с высоким социальным статусом, дети мотивированы для учебы, происходит отбор в такие школы, в них выше, чем в соседних школах, результаты ЕГЭ), другие «непрестижными» (в них записывают всех тех, кто не попал в окрестные «хорошие» школы). Таким образом «хорошие» школы» могут соседствовать с «плохими» в непосредственной близости, на территории одного микрорайона [Ястребов и др. 2013].

Мы выбрали для проведения исследования в Подмосковье «устойчиво неуспешные школы», т.е. «школы, которые в течение продолжительного периода демонстрируют по определенным показателям учебные результаты хуже, чем все остальные» [Пинская и др. 
2011: 152]. Также выбранные нами школы Подмосковья являются участниками государственной программы Министерства образования Московской области для школ «со сложным социальным контекстом».

Что касается Москвы, то у нас не было доступа непосредственно в школьные комплексы. Однако при отборе учителей и учеников для интервью мы также исходили из имеющихся у нас данных. Наши собственные исследования [Деминцева, Пешкова 2014; Demintseva 2017] позволяют говорить, что дети мигрантов в Москве часто попадают в «непрестижные», «плохие» школы районов города. Поскольку мигранты селятся в Москве во всех районах и нельзя говорить о существовании «этнических» или «мигрантских» районов [Деминцева, Пешкова 2014; Demintseva 2017], то школы, в которых есть значительное присутствие детей мигрантов, можно найти в любой части города. Дети мигрантов попадают чаще в «плохие» (низкие рейтинги ЕГЭ) школы районов, куда их охотно берут из-за недобора учащихся. Сегодня в Москве школы объединены в учебные комплексы, однако в одном комплексе может быть как «престижная» школа, так и «плохая». Дети мигрантов, как правило, концентрируются в последней. Выборка учителей, работающих в школах Москвы, была в основном случайной, проводилась методом «снежного кома», когда одни учителя рекомендовали пообщаться с коллегами из школ, «в которых тоже много мигрантов». Дети мигрантов также отбирались в основном случайно: мы провели интервью в нескольких волонтерских школах, которые помогают в учебе детям мигрантов, а также интервью с детьми, которые учатся в «плохих» школах Москвы.

\section{В КАКИЕ ШКОЛЫ ПОПАДАЮТ ДЕТИ МИГРАНТОВ?}

«К нам отправляют всех, кого другие школы не взяли: кто плохо учится, у кого проблемы какие, детей мигрантов. Всех к нам, в XX школу!», - комментирует ситуацию директор одной из Подмосковных школ, в которой мы проводили исследование. Эта фраза повторялась администрацией всех школ, в которых мы побывали. Обычно школы, в которых учится много детей мигрантов, имеют схожую историю: школа приходит в упадок, в нее не хотят отдавать детей жители окрестных домов, в школе происходит недобор учащихся, и администрация начинает «добирать» учеников теми детьми, которых не хотят принимать в другие школы района. Мигранты попадают в категорию детей, «которых не хотят брать».

«На самом деле, вот почему у школь такая сложилась история. 4-5 лет назад было подушевое финансирование, и директор откровенно нам сказала, что, вот, она просто набирала всех подряд, всех, кто к ней шли, даже из соседних школ. Говорили: "Идите в ХХ, вас там возьмут - там всех берут". И так получилось, что их стало настолько много, детей из Средней Азии, что русские дети постепенно стали уходить из школь»», комментирует учитель ситуацию возникновения «мигрантской» составляющей в одной из московских школ.

Школы, в которых мы проводили исследование, имели схожие характеристики. К ним можно отнести:

1) худшая школа по своим учебным показателям в районе, городе (поселке, поселении); 
2) самая «непрестижная» школа. Именно так она охарактеризовалась среди местного населения;

3) школа в советские годы была «на хорошем счету», по рассказам директоров, «слом» произошел в 1990-е. К основным причинам можно отнести смену жителей районов и городов, уменьшение финансирования школ. Также, как правило, во всех школах в 1990-2000-е годы были директора, не пытавшиеся «выровнять» ситуацию, или же была частая смена руководства;

4) основной контингент записывающихся в школы - дети из социально неблагополучных семей, многие дети из неполных семей, дети из семей мигрантов;

5) во всех школах был недобор учащихся в классах (10-11-е классы по 12-18 человек).

По оценке и учителей, и администрации школ, несмотря на то, что эти школы записывают к себе большинство детей из семей иностранцев города, нельзя говорить о большом числе детей, приехавших из других стран, в классах школы. Оценки мало расходятся от школы к школе, детей, приехавших в основном из стран СНГ, примерно 2-4 в старших классах школы, в средней школе в классе 5-6 человек. Большее число детей учится в начальной школе: в классах из 28-30 человек детей мигрантов из других стран 79. Эти дети могут как иметь российское гражданство, так и нет. Некоторые приехали в Россию давно, для других это первый год учебы в российской школе. Как отмечали директора школ и учителя младших классов, в последние 3-4 года число детей, приехавших из других стран, в младших классах увеличивается. «Bы понимаете, мигранты привозят детей, когда уже устроены здесь. У папы стабильная работа, они могут снять квартиру. Поэтому детей не так много в городе. Не все мигранты из других стран могут себе это позволить», - комментирует ситуацию директор школы подмосковного города.

В большинстве школ, в которых проходило исследование, недавно (3-4 года назад) поменялся директор. Новые директора были направлены в эти школы, как правило, для устранения уже существовавшей в них «сложной ситуации». «Я когда вошла в школу, посреди коридора стоял старшеклассник в трениках и курил! Он знал, что я новый директор, но ему было все равно. Вот такие были здесь нравы», - рассказывает о своем опыте директор одной из подмосковных школ. Главные проблемы, с которыми пришлось столкнуться новым директорам, были связаны, по их словам, с присутствием в школе детей из социально неблагополучных слоев (дети людей, страдающих алкогольной зависимостью, дети из неполных семей), часто не мотивированных к учебе. Со стороны учителей тоже не было мотивации помощи отстающим по школьной программе детям, интереса к неблагополучным семьям и т.п. Описывая ситуацию, с которой столкнулись новые директора при назначении в эти школы, ни один из них не назвал присутствие детеймигрантов основной проблемой для школы или хотя бы проблемой первого ряда, с которыми они столкнулись, получив это назначение.

В двух школах из восьми, где проводилось исследование в Подмосковье, 3-4 года назад были созданы кадетские классы. Таких классов сегодня насчитывается 5-6 в каждой школе. Запись в них осуществляется на добровольной основе при согласии детей и родителей. По нашим наблюдениям, в кадетских классах мало детей мигрантов (1-2 человека на класс), тогда как в параллельном «простом» классе может быть 8-10 человек. Это же подтвердил и заместитель директора одной из школ: дети мигрантов редко 
записываются в кадетские классы, в основном туда идут «местные». Хотя в младших классах стали появляться в этих классах и дети из мигрантских семей.

Школы в Подмосковье, в которых мы проводили исследование, имели либо классы для детей с особенностями развития (в 2016 г. их расформировали, дети разошлись на домашнее обучение или в другие классы школы), либо классы вечерней школы. Школа включала в себя разный контингент учащихся (инвалиды, «сложные дети»), который не «вписывался» в другие школы. На протяжении многих лет школы были теми учебными заведениями, в которые целенаправленно записывали детей, которые не попадали в рамки «нормальных» учеников: дети «проблемных» родителей, дети-инвалиды, дети, не справляющиеся со школьной программой. С появлением детей мигрантов в них также стали записывать и эту категорию детей. «Если там ученик не нужен или не дотягивает - сразу отправляют к нам. Знают, что мы всех берем», - комментирует ситуацию директор одной из таких школ.

Еще одним вариантом выделения в школах детей мигрантов может быть создание в школе класса, в котором учатся дети из «группы риска». По рассказам одной из учительниц подмосковной школы, именно так формируются классы в их учебном заведении: «B нашем городе дети-учашчеся приходят [в школы] по территориальному признаку. Поэтому выбор за родителями остаётся как бы условныл. А вот внутри самой школь идёт градация... Скажем, почётного звания учителя я не имею, вынуждена работать как раз с детьми «группь риска». Это дети-инвалиды и «дети группь риска». - э это что за «группа риска»? - ... Это многодетные семьи, это дети, над которыми взяли опеку. Это дети, которые имеют медицинские отклонения, это могут быть дети, у которых ослаблена сила воли, и они, скажем так, нарушают дисциилину, но это медицинские показания». В такие классы, по словам учителей, часто попадают и дети мигрантов. Обычно программа в них облегченная, поэтому администрация школ переводит туда детей мигрантов, в особенности тех, у кого проблемы с русским языком.

Пришедшие в школы работать несколько лет назад директора пытаются решать вопросы, связанные не только с учебой, но и с социальными проблемами учеников. Так, в двух школах в обязанности классных руководителей входит посещение всех учеников класса у них дома для понимания ситуации, в которой живут дети. Это не входит в обязанности учителей, но, поскольку в этих школах администрация постоянно сталкивается с социальными проблемами, она просит классных руководителей взять под контроль не только успеваемость, но и личную жизнь ребенка (ребенок перестает ходить в школу, и не могут найти его родителей; ребенка увозят в другой город, не информируя школу; родителей лишают родительских прав, а администрация не знает, кто назначен опекуном; ребенок должен перейти на обучение в интернат - вот список проблем, называемых директорами школ).

Школы пытаются взаимодействовать с различными городскими образовательными и спортивными центрами в своем городе, делают совместные программы (так, в одной из школ Подмосковья директор подписала договор о социальном партнёрстве с центром социально-психологической помощи, в котором работают психологи, логопеды, дефектологи, у них есть договоренность о дополнительной работе с детьми мигрантов). Но 
это единичные примеры, такие инициативы идут, как правило, от самих директоров, которые используют любые возможности для поддержания образовательного уровня школы.

Таким образом, «мигрантские школы» - это те учебные заведения, в которые не хотят отдавать своих детей «местные» не только из-за уровня образования (низкий уровень ЕГЭ), но и из-за социального контекста. В этих школах, как правило, еще до появления в них детей мигрантов обучались дети, которых не брали в другие школы (например, инвалиды или дети из неблагополучных российских семей), или же в них переводили детей из «хороших» школ из-за неуспеваемости в учебе или плохого поведения. Сегодня эта ситуация «усложнилась» фактом наличия мигрантов. «Нашу школу называют в городе «черной», потому что у нас много детей мигрантов», - комментирует завуч подмосковной школы. Если даже для самой школы присутствие детей мигрантов не является основной проблемой (основными проблемами учителя называют присутствие детей из неблагополучных семей, детей-инвалидов, в особенности в последний год, когда отменили специальные классы для них), именно мигранты сегодня являются для местных жителей показателем «неблагополучности» школы. Чем больше становится детей мигрантов в таких школах, тем больше уходят оттуда дети «местных», чьи родители не хотят, чтобы дети были с ними в одном классе.

\section{ПРОБЛЕМЫ «ВХОЖДЕНИЯ» ДЕТЕЙ МИГРАНТОВ В ШКОЛЫ}

Эксперты полагают, что для успешной адаптации мигранта к жизни в принимающем обществе он должен преодолеть три основных барьера: он должен овладеть знанием государственного языка, пониманием основных исторических и культурных ценностей страны, способностью к соблюдению бытовых норм поведения [Rumbaut 1995; Омельченко и др. 2010]. Для детей мигрантов школа является важным, а часто и единственным значимым социальным институтом, выполняющим функции по их адаптации не только в классе, но и в принимающем обществе в целом. Именно там они интегрированы в сообщество класса, основной язык общения в школе - русский, они проходят ту же программу, что и другие ученики.

По законодательству РФ тесты для поступления в государственную школу детям иностранцев сдавать не нужно. На данный момент основным документом, определяющим порядок зачисления детей в школу, является приказ Министерства образования и науки Российской Федерации от 22 января 2014 г. № 32 «Об утверждении порядка приема граждан на обучение по образовательным программам начального общего, основного общего и среднего общего образования». Согласно данному приказу существуют два пакета документов, необходимых для зачисления ребенка в школу. Первый - для детей, имеющих гражданство РФ, и второй - для иностранных граждан и лиц без гражданства. Для записи ребенка в школу требуются: заявление от родителей; ксерокопия свидетельства о рождении; справка о регистрации; медицинская справка 026/y. В дополнение к этим документам «родители детей, являющихся иностранными гражданами или лицами без гражданства, предъявляют документ, подтверждающий родство заявителя (или законность 
представления прав ребенка), и документ, подтверждающий право заявителя на пребывание на территории Российской Федерации»².

Администрация и департамент образования города обязаны записать ребенка в государственную школу при наличии в ней мест. Но в реальной жизни возникает несколько трудностей, которые вынуждают мигрантов в худшем случае отказываться от услуг московских и подмосковных школ и не записывать в них детей, либо искать различные пути решения проблем.

Первая проблема - это регистрация через сайт госуслуг (для Москвы). Мигранты часто боятся официально регистрироваться на государственных сайтах. Даже если у них есть все документы, они боятся вносить их в какие-то базы данных. На наш взгляд, это связано прежде всего с тем, что многие не уверены в подлинности каких-то документов, а в некоторых случаях точно знают о том, что они куплены. Например, наиболее часто покупаемый мигрантами документ - это регистрация по месту жительства, обязательное наличие которой требуют все школы, так как необходимость его наличия прописана в документе об образовании (хотя можно усомниться в обязательности его предъявления, если внимательно читать формулировку документа [Троицкий 2017]). Документы покупаются у «посредников», адреса и телефоны которых мигранты передают друг другу. Директора учебных заведений осведомлены о том, что дети чаще всего не живут по адресу, указанному в этом документе, так как знают о том, что родителям трудно зарегистрироваться по месту жительства [Деминцева, Пешкова 2014]. Однако так как они обязаны принимать в школу ученика только с регистрацией, им приходится закрывать глаза на то, что, возможно, документ куплен.

Вторая возникающая проблема - это отказ некоторых школ записывать в них детей. Обычно администрация школ отказывает со ссылкой на их наполненность (что часто верно, так как лучшие школы города и региона обычно комплектуют свои классы еще в конце мая). Поэтому, как мы и описывали ситуацию выше, дети мигрантов чаще попадают в те школы, в которых остались места, потому что туда не хотят отдавать детей «местные». Но, столкнувшись с отказом, мигрант может вообще отказаться от идеи отдавать ребенка в школу.

Наконец, третья проблема - несоответствие возраста ученика тому классу, в который его определяют. Программы многих стран, откуда приезжают дети, отличаются от той, которая реализуется в российской школе. Также ребенок может не говорить по-русски и это затрудняет процесс осваивания им программы других школьных предметов. Поэтому детей мигрантов, особенно учеников средней школы, отправляют в класс на год или два младше, чем тот, которому он соответствует по своему возрасту. Дети часто оказываются в позиции аутсайдера и испытывают сложности с включением в коллектив. И даже записав ребенка в школу, родители сталкиваются с ситуацией, когда сам ребенок отказывается ее посещать.

- A здесь? Tы пошел в школу в начале сентября?

2 Приказ Министерства образования и науки Российской Федерации от 22 января 2014 г. № 32 «Об утверждении порядка приема граждан на обучение по образовательным программам начального общего, основного общего и среднего общего образования». 
- Я не хотел. Думал, тяжело, боялся.

- Но тебя отдали в школу?

- Hem.

- То есть тебя родители хотели отдать, но ты отказался?

- Отказался. Да.

- Ты ни разу даже не был в школе? Даже в классе ни разу не посидел?

- Бblл.

- Сколько?

- Ну, там, после Нового года были там... сказали, поздно уже, надо в сентябре.

- В январе были? Сказали, что надо в сентябре приходить? И ты пойдешь в сентябре в школу?

- Не знаю. Думаю, да.

....- Ты почему не хочешь в школу?

- Боишься.

- Чего боишься?

- Как-то я не могу как все. Слабый.

- Ты не можешь по-русски говорить, как все?

- Да.

- Hу, ты хорошо говоришь.

- У меня проблемы с письмом. Я не могу нормально писать.

(Из интервью с 14-летним мальчиком из Оша, Киргизия).

Ситуация забюрократизованности процесса оформления в школу, отказ некоторых школ принимать детей мигрантов или же страх перед записью через портал госуслуг создают среди самих родителей-мигрантов мифы вокруг этой ситуации. Например, согласно одному из распространенных мифов, детей с незнанием русского языка могут не взять в школу, если они не пройдут тест на знание языка. По закону тесты для поступления в школу не нужны, однако миф рождается не на пустом месте. Обычно детей младших классов просто записывают в школу, тогда как в среднюю школу их также записывают, но директора школ дают детям мигрантов тестовые задания для определения их уровня подготовки. Эти задания обычно разрабатываются учителями той же школы, не существует каких-то общих критериев для всех школ, но благодаря им директор понимает, может ли он записать ученика в класс, соответствующий его возрасту, или нет. Таким образом, если официально теста при приеме в школу нет, то неформально директора вынуждены его проводить. По заверению директора одной из подмосковных школ, это вынужденная мера, так как если не определить уровень знаний ученика средней школы во время его поступления, то в течение первых же месяцев учителя столкнуться с тем, что ученик не 
может включиться в учебный процесс и наравне с другими учениками выполнять задания. И все равно его придется переводить в младшие классы.

По заверениям директоров школ, с такими ситуациями им приходится сталкиваться 2-3 раза в год и каждый раз в индивидуальном порядке их решать. Они не имеют права не записать ребенка в школу или же, при плохих показателях, попросить его уйти из школы. Но иногда дети, переживающие стресс из-за этой ситуации, сами перестают посещать учебные заведения. Это и рождает миф в мигрантской среде о тестах, которые могут закрыть дорогу ребенку-мигранту в школы. В неформальных беседах родители мигрантов часто сами высказывают опасения относительно того, сможет ли их ребенок, не говорящий/плохо говорящий по-русски, попасть в московскую или подмосковную школу.

Приехав в Москву и Подмосковье, некоторые дети мигрантов могут подолгу находиться вне школы. В некоторых ситуациях родители-мигранты сознательно оставляют ребенка дома. Например, девочку или мальчика лет десяти могут оставлять сидеть с младшими детьми, пока родители на работе. По рассказам 11-летней девочки-киргизки, ее родители привезли на лето для того, чтобы она присматривала за 2-летней сестрой. Но, когда начался учебный год, они ее оставили на месяц, потому что некому было сидеть с ребенком, потом еще на один. В школу ее не записывали, по ее словам, так как все время хотели отправить на родину. Интервью проводилось в апреле, девочка уже почти год жила в России, но ни разу не ходила в школу. Обычно мы ничего не знаем о таких детях, сколько их, как они проводят время, когда они приезжают и уезжают на родину. Привозя их в Россию, родители могут никаким образом не оформлять их в стране, и довольно сложно узнать об их существовании в России.

Таким образом, при наличии упомянутых нами ранее документов мигрант может записать своего ребенка в школу. Однако могут возникнуть проблемы, связанные со страхом записи через портал госуслуг, возможностью получения отказа от школы либо беспокойством за своего ребенка, который столкнется с ситуацией понижения класса и незнания языка. На сегодняшний момент мы можем знать ситуацию только с теми детьми, которые записаны в школы. Однако, что происходит с детьми мигрантов, которые не записаны ни в какие учебные заведения, сколько их и как планируют их родители их «встраивание» в российскую жизнь, узнать практически невозможно.

\section{ПРОБЛЕМЫ АДАПТАЦИИ ДЕТЕЙ МИГРАНТОВ В ШКОЛАХ}

Главная и, пожалуй, самая очевидная проблема, с которой сталкиваются ученики-мигранты при поступлении в школу, - это слабое знание или незнание русского языка. Проблему с включением в детский коллектив называли нам те дети мигрантов, которые по приезде в страну не говорили или плохо говорили по-русски. «В чем заключались проблемы? Вначале, как бы там.. не хорошо знаешь русский язык. - И что? - Издеваются. Издеваются? - Ну да, бывает такое», - объясняет ситуацию школьник из Средней Азии.

Одним из тяжелых периодов дети мигрантов, не говорящие при приезде или плохо говорящие по-русски, назвали свой первый год обучения. Многие вспоминали о нем, как о «периоде молчания». «Я молчала, потому что мне не нравилось, когда меня поправляют, я 
хотела уже нормально говорить по-русски, я читала книги, смотрела фильмы и я хотела уже нормально как заговорить и потом уже завести друзей», - делится опытом девушка из Армении, которая приехала в 3-м классе в Россию. «Человек, который приехал в Россию и не знает русского языка. Ему надо сначала выучить, потом только общаться. И он только тогда станет наравне с другими ребятами, которые уже знают русский», комментирует ситуацию другой школьник, приехавший несколько лет назад в Россию из Таджикистана.

«Да я как-то... первый год вообще ни с кем не общалась в классе. Я больше ходила одна. А после этого, когда уже подружилась с ребятами, я им помогала, они мне помогали, кто что мог», - делится своим опытом 9-классница. Обычно после первого года обучения дети начинают говорить по-русски. Первый год они посещают наравне с другими детьми уроки, но, как правило, отстают по программе, так как не всегда понимают, что происходит вокруг них. Специальных уроков для помощи детям мигрантов не существует. Но поскольку учителя должны работать по программе со всем классом, они пытаются найти время для дополнительных занятий с этими детьми. Обычно они просят их прийти раньше, до начала занятий, или же после уроков. «Какой у вас подход к этим детям, у которых есть проблемы с русским языком? - Много [в классе] читаю, объясняю, даже оставалась после уроков с этими детьми... То есть потихонечку, постепенно это выравниваем», делится опытом учительница младших классов. Но, по признанию учителей, этого времени мало, часто они просто помогают решать текущие задания, никакой методической литературы, учебников для детей-иностранцев в школах нет.

С появлением все большего числа детей-иностранцев, не говорящих по-русски, директора стараются решить проблему незнания русского языка. Как мы уже упоминали, это может быть контракт с центром социально-психологической помощи, в котором работают психологи, логопеды, дефектологи. Дети мигрантов ходят туда на дополнительные занятия русским языком после школы. В другой школе часы бесплатного кружка отдали для занятий русским языком с иностранцами. Но ни в том, ни в другом случае учителя не имеют никакой специально разработанной программы обучения детейиностранцев языку. Такая инициатива обычно исходит от директора, который понимает сложность ситуации и пытается ее решить всеми возможными способами.

«Есть один учащийся, которому... нет, с речью, с говорением, все в порядке. Мы встречаемся с проблемой понимания. Почему - потому что внутри они же все равно мыслят на своем родном языке, правильно? И чтобы проработать ту информацию, которая к ним поступает, естественно, тут проблема и есть. Поэтому мы стараемся больше углубиться в изучение, вот, фонетики, работаем. Кстати, Юлия Владимировна, до меня коллега была, она именно учитель-логопед, вот с этими детками она занимается индивидуально. На базе нашей школь у нас есть даже как вид по программе деятельность, которая так и называется: «Речевая копилка». И естественно, эти детки все, совершенно все, ходят на эту «речевую копилку».

Все же большинство детей приезжает в Россию со знанием русского языка. Это дети украинцев, белорусов и молдаван, выходцы из тех стран, в которых во многих семьях говорят либо на русском, либо на русском и на родном языках. Дети из стран Кавказа и 
Средней Азии тоже иногда приезжают со знанием языка: многое зависит от региона, откуда они родом (есть русскоязычные регионы, как, например, Бишкек), и социального статуса родителей (дети могли ходить в своей стране в русские школы, в семье говорят на двух языках). Как показали проведенные нами фокус-группы, лишь небольшая часть детей испытывала сильные трудности с языком. Большая часть детей к моменту переезда уже свободно говорили на русском языке. Однако, по заверениям учителей, ситуация ухудшается. Как показывают исследования последних лет [Флоринская и др. 2015], сегодня в Россию приезжает все больше людей с низким социальным статусом, без образования, выходцев из деревень. Не многие из них привозят детей (это слишком дорого, они не могут позволить оформить все документы и снять удобное жилье для проживания с детьми), но все же увеличилось число детей из семей, в которых родители не говорят по-русски. И если среди опрошенных нами старшеклассников таких детей было немного, то можно ожидать их увеличения в следующих поколениях.

Еще одна проблема, с которой сталкиваются и дети, и родители мигрантов, связана с дискриминацией и ксенофобией в школах. В современной российской школе толерантность - это норма, она воспринимается учителями и руководством как формальная ценность, прописанная в уставных документах. Интервью показали, что в большинстве случаев учителя отрицают ксенофобию как социальное явление в школе. При общении с директорами школ, которое выходило за рамки официального интервью, поскольку они координировали нашу работу в школах, тема ксенофобии затрагивалась неоднократно. Они указывали на то, что в младших классах дети практически не замечают этнического различия. Негативные высказывания в адрес другой национальности начинают транслироваться в возрасте 9-10 лет и обычно повторяют существующий дома дискурс. Задачей учителей является затушить эту ксенофобию, определив для детей рамки отношений между ними.

По свидетельству киргизки, матери троих детей, ее дочь пришла учиться в московскую школу, закончив два класса русской школы в Киргизии. Девочка попала во второй класс, она хорошо владела русским языком, но, по словам матери, ей все равно было тяжело учиться в школе. Были трудности в освоении школьной программы, которая отличалась от той, что была на родине, а также возникли проблемы в отношениях с детьми в классе. «Они спросили, как меня зовут, - рассказывает ее дочь, - я сказала, они начали смеяться, я играла с одним мальчиком, он не смеялся, другие не разговаривали со мной... Все мальчики дразнили меня «китайщем», потому что у меня глаза узкие. Потом меня один мальчик пинал и по голове бил, я сказала учительнище, и она их поругала, она сказала: "Она из другой страны приехала», и потом они перестали».

На институциональном уровне кроме декларативной/формальной толерантности в школах не существует специальных обучающих программ ни для учителей, ни для учеников, в которых бы поднималась проблемы ксенофобии и расизма. Тем не менее некоторые учителя говорят о том, что проводят беседы на тему толерантности в рамках классных часов. Однако эти беседы редко являются детальным разговором об особенностях разных культур и зачастую сводятся к трансляции стандартизированной нормы, принятой на официальном уровне. Складывается впечатление, что и сами учителя не совсем понимают, на каком языке говорить об этой теме, какие приводить аргументы в пользу 
хорошего отношения друг к другу. Многие предпочитают не выходить за рамки существующего стандартного набора фраз, немного даже отстраняясь от этой темы.

С одной стороны, школа является территорией, на которой действуют жесткие формы дисциплинарного контроля, которые de jure ограничивают распространение ксенофобии. Ни в одном интервью ни ученики, ни учителя не отзывались негативно об этнических меньшинствах или же о «местных» детях. Эта тема является сегодня своего рода табу в официальном дискурсе школы. Однако полностью отрицать существование ксенофобии нельзя. Зачастую ксенофобия существует на безрефлексивном уровне и не воспринимается дискриминирующим как нечто негативное. Существование подобной латентной ксенофобии можно объяснить различием между официальной и бытовой нормами, последняя из которых устойчиво закрепилась в русском обществе.

Таким образом, в современной российской школе ребенок с миграционной историей испытывает дополнительную социальную нагрузку, которая определяется, прежде всего, психологическими сложностями вливания в новый коллектив, в некоторых случаях с незнанием или слабым знанием русского языка, а также с возможными проявлениями ксенофобии со стороны учеников. В первый год некоторые дети мигрантов предпочитают «отмалчиваться», когда другие могут в агрессивной форме отстаивать свое равенство с другими.

- Кто вспомнит, как удалось удачно наладить общение [в первый учебный год]?

- Да. У меня была драка с одним из нашего класса......Сразу после этого слились с компанией. Он [с кем подрался] каждый раз, когда я приходил [до драки] в школу, ... ждал, туда... хач... туда-сюда. После, как подрались с ним, и он перестал обзывать. Так и в коллектив влился.

- А с ним как у вас отношения?

- Сейчас нормальные.

Помимо трудностей адаптации первого года, языковых для одних и психологических практически для всех наших собеседников (новая школа, коллектив, стресс переезда), никто не мог назвать проблем в последующие годы. «...В четвёртом классе... приехал, это было летом. Самые элементарные вещи знал, здрасьте, там, и ещё что-то. То, что нужно в школе, чтобы спросить. Писать умел, а дальше с друзьями, с одноклассниками общение, все дела. И месяиа четыре где-то понадобилось, чтобы общаться нормально. Как все», - рассказывает ученик подмосковной школы. Некоторые дети указывали, что год - это максимальный срок. При знании языка это скорее месяца двачетыре, когда происходит привыкание к одноклассникам, завязывается дружба с кем-то.

В этот же год появляются первые и наиболее острые проблемы с одноклассниками. Ребенок воспринимается ими как «чужой»: «Национальность не имеет значения. Могли они что-то предложить, если я отказывалась, не то, чтобы они меня гнобили. Я не была такая как они, но это не из-за национальности. У меня было другое воспитание, они могли гулять допоздна, они могли гулять с мальчиками, но у меня было другое воспитание. Я сначала должна уважать мнение своих родителей, потом уже думать о себе», - рассказывает 
девушка, приехавшая в шестом классе в школу. Многие дети мигрантов, проучившиеся несколько лет в школе, вспоминают, что с появлением первых друзей постепенно проблемы уходили. Они не могли выделить какие-то новые для себя проблемы, говорили, что сталкиваются в школе с теми же трудностями, что и другие одноклассники.

Таким образом, попадая в школу, в первый год дети мигрантов сталкиваются с несколькими главными проблемами, затрудняющими процесс адаптации. Первая - это незнание русского языка для некоторых детей. И для таких детей требуется как минимум год, чтобы не только научиться говорить, но и начать общаться с одноклассниками. Вторая проблема, которая охватывает уже всех детей мигрантов, - это психологические сложности адаптации в новом для себя коллективе. Но, описывая их, дети отмечали такие проблемы, как страх перед новым классом, многие скучали по своим прошлым одноклассникам, называли сложным период первых месяцев, когда еще не можешь отнести себя ни к одной классной компании. Однако такие же проблемы называли и «местные» ученики, которым приходилось переводиться в другую школу. И наконец, третья проблема - проявление ксенофобии со стороны учеников, которая со временем, по признанию многих, становится менее насущной.

\section{ИЗМЕНЕНИЕ ШКОЛЬНОГО ПРОСТРАНСТВА ПОД ВЛИЯНИЕМ ВНЕШНЕЙ МИГРАЦИИ}

С одной стороны, школьное пространство московского региона является наднациональным. Система школьного образования Москвы и Подмосковья не нацелена на поддерживание этнокультурного многообразия. С другой стороны, интенсификация как внутренней, так и внешней миграции за последние два десятилетия изменила этнический состав московских и подмосковных школ, что не могло не сказаться как на внеклассных и образовательных практиках внутри школ, так и в целом на современном школьном пространстве московского региона.

Данные исследования показали, что происходит «этнизация» школьного пространства. Понятие «этнизации» требует уточнения. Этнологи В.И. Дятлов и К.В. Григоричев понимают «этнизацию», как «актуализацию этнического фактора в повседневной жизни, социальных и политических отношениях, в механизме формирования социальных связей и отношений, маркировании их этническими категориями» [Дятлов, Григоричев 2014: 8]. Мы согласны с таким определением и считаем, что понятие, которое ученые используют для описания явлений городской повседневности, может быть применимо и к школьному пространству. Так или иначе, этническое становится артикулированным в школах: во внеклассных мероприятиях, в меньшей степени в рамках образовательного процесса, а также в повседневности.

Одним из новых предметов, на который указывали учителя как на дисциплину, в рамках которой обсуждается с учениками культурное и религиозное разнообразие, был введенный в декабре 2010 г. курс для 4-го класса «Основы религиозных культур и светской этики». Курс направлен, как это прописано в официальных документах, на «формирование у младшего подростка мотиваций к осознанному нравственному поведению, основанному 
на знании и уважении культурных и религиозных традиций многонационального народа России, а также к диалогу с представителями других культур и мировоззрений» ${ }^{3}$. Ученик, как это предусмотрено по программе, может выбрать один модуль из шести: «Основы светской этики»; «Основы православной культуры»; «Основы мировых религиозных культур»; «Основы буддийской культуры»; «Основы исламской культуры»; «Основы иудейской культуры». Хотя дети могли выбирать один из этих шести модулей, на практике они посещали один из предложенных им в школе двух или трех. По словам директоров и учителей, в школе в реальности чаще преподавали «Основы светской этики», «Основы православной культуры» и «Основы мировых религиозных культур», так как по другим предметам не было специалистов. Хотя практически в каждом классе из обследуемых нами школ обучались дети этнических мусульман, никто из них не посещал курс «Основы исламской культуры». Некоторые из детей мигрантов-мусульман записывались на курс «Основы православной культуры», преследуя, по словам учителей, ознакомительные цели. Большая же часть родителей-мигрантов выбрали для своих детей «Основы светской этики». В единицах школ преподавался модуль «Основы мировых религиозных культур», который, по замечаниям учителей, вызывал особенный интерес у учащихся мигрантов:

«Вести «Основы мировых религиозных учений» сложно, потому что там [в классах] много мусульман, там и немало, собственно, христиан, православных. И когда речь заходит, скажем, о Коране или об исламе, сразу включаются дети-мусульмане, когда речь заходит о христианстве, то это почти никому не интересно. Ну, такая вещьь... Если мы говорим об исламе, они все включаются, то есть это часть их идентичности и это очень резко обострено, если даже, когда ты спрашиваешь, кто такой порок Мухаммед, они не знают, но они все думают, что они знают лучше всех...», - рассказывает преподаватель истории, «Основ светской этики» и «Основ мировых религиозных культур» в одной из московских школ. В другой школе преподаватель истории и «Основ православной культуры» поделилась своими соображениями, что этот курс очень удобен для интеграции детей в российское «православное» общество. Более того, на базе школы был создан православный театр, в который учителя приглашали и представителей других религий.

Популярной формой внеклассного мероприятия стали так называемые «Дни национальных культур» или «Фестиваль национальных культур». Такие мероприятия чаще всего проводятся в первых числах ноября, рядом с датой празднования «Дня народного единства», но могут проходить и в другие месяцы. Чаще всего знакомство с этнической культурой ограничивается танцевальным номером или небольшой театральной сценкой, как правило, на таких мероприятиях угощают всех собравшихся национальной едой, которую помогают приготовить родители. Масштабы мероприятия разнятся: в каких-то школах все сводится к однократному выступлению в актовом зале, в котором может быть задействован только один класс, другие же учителя запускают годовой проект, состоящий из серии мероприятий, подготовка к которому длится не одну четверть, а участие

\footnotetext{
3 Приказ Министерства образования и науки Российской Федерации от 22 января 2014 г. № 32 «Об утверждении порядка приема граждан на обучение по образовательным программам начального общего, основного общего и среднего общего образования».
} 
принимает вся школа. Некоторые школы ограничивают набор национальных мероприятий только теми культурами, представители которых учатся в школе, другие же пытаются охватить весь мир, например, в одной из школ были выбраны Бразилия и Великобритания. По заверению учителей, обычно ученики в классе сами между собой договариваются, какую национальность они будут представлять. Как правило, на выбор школьной администрацией дается несколько стран, из которых и делается школьниками выбор. Однако этот набор ограничен, и, как можно предположить, все же выбор в большинстве случаев координируется учителями.

«... когда я пришла в эту школу и, увидев, что такая школа многонациональная, мьы проект запустили - у нас называется «Фестиваль национальных культур». Но фестиваль - это уже кульминация проекта, а весь год мы собираем какие-то материаль: дети изучают особенности начиональной культуры, особенности национального костюма, особенности национальной кухни, мы приглашаем родителей, потому что родителей же тоже надо задействовать, и мы приглашаем родителей, родители тоже нам рассказывают, ну вот, особенно мамы любят там о кухне рассказывать, о прическах начиональных..., в преддверии самого этого праздника они готовят эти блюда, и вот мы накрываем такой большой стол, где разные национальности выставляют свое, причем национальные именно блюда..., мы представляем только те национальности, дети которых обучаются в нашей школе. Вот армяне есть -мы представляем, вот узбеки есть - представляем, евреи есть - представляем... Причем они представляют песни, таниы, о стране рассказывают, рассказывают, какие великие люди - выходиь их национальности, да, про них. В общем, в этом году будет уже четвертый год, и оно приобретает все больший размах, это мероприятие, потому что дети к нему готовятся, но не просто так, что вот пришли и там танец станцевали и ушли. Такого не бывает», - рассказывает директор одной из Подмосковных школ. Похожую практику описывает и завуч одной из московских школ. В одном из зданий учебного комплекса сконцентрировано много детей мигрантов, поэтому администрация решила сделать похожий фестиваль, привлекая к его организации родителей детей мигрантов.

Необходимо отметить, что такие фестивали (по сути - программы по работе с многоэтничным коллективом детей) и другие подобные формы работы в таких школах являются инициативами их директоров и учителей. Эти длительные по времени проекты не являются обязательными, но администрация и учителя чувствуют необходимость их создания в школах: «Нас и так все вокруг плохими считают, что у нас тут мигрантов много, так мы это делаем плюсом, показываем какая у нас школа многонациональная»"», делится с нами ее директор.

Отдельного упоминания заслуживает проблема присутствия/отсутствия родных языков детей мигрантов в рамках школьного пространства. Как мы уже упоминали, основной проблемой, с которой сталкиваются как дети мигрантов, так и учителя, оказывается незнание или чаще всего недостаточное знание некоторыми учениками русского языка. Проблемы с русским языком сказываются как на социализации учеников, так и на их общей успеваемости. Поэтому учителя озабочены тем, чтобы дети как можно быстрее начали свободно говорить на русском языке. Учителя просят родителей 
максимально сократить общение с детьми на родном языке в семейном пространстве, запрещают детям говорить друг с другом на родном языке на переменах.

«Bот у меня в классе есть ещче один Гриша, у него две старших сестры. Они, когда на перемене к нему спускаются узнать, как он себя чувствует, ... сразу начинают на своем языке разговаривать. Мы просим, конечно, в нашем присутствии так не делать, потому что непонятно. Но не так, чтобы ругать. Но просим, чтобы на нашем языке. И родителей просим и индивидуально, и на собрании, когда остаются, чтобы спросить, как мой ребеночек, чтобы на русском больще общались с такими детьми».

«Они могут даже заговорить на своем где-то, хотя мы как-то вот говорим, раз уж, вот, в школе все говорят на русском, давайте, вот, на русском, значит, и говорить. Потому что, ну что вы там сказали, может, посмеялись над кем-то, может еще, так некрасиво».

Подобная запретительная практика напоминает позицию преподавателей в советских и российских сибирских интернатах, в которых учились и продолжают получать образование дети из числа коренных народов [Лярская 2006]. Тотальное исключение родного языка из школьного пространства затрудняет адаптацию детей в инокультурной и иноязыковой среде. Ощущение свободы и уверенность в помощи билингвальных земляков - необходимые факторы, способствующие успешной адаптации нового ученика. Многие исследования показали, что дети мигрантов социально и академически успешнее в школах, если они не принимают ассимиляционную образовательную стратегию и, наряду с изучением принимающей культуры и местного языка, сохраняют родной язык и родную культуру [Deyhle 1995; Gibson 1988; Mehan et al. 1994].

Стоит отметить, что иногда некоторые учителя интересуются культурой и языком своих иноэтничных учеников, не исключают их культуру и язык из школьного пространства, а напротив, включают: «... мы им не навязываем, а наоборот, у них спрашиваем: а как у вас проходит вот этот праздник, а как у вас происходит вот то-то, то-то. У них, наоборот, мы пытаемся познать, а как вот у них в семьях, а насколько они вообще придержсиваются своих народных традиций, вот мы с этой позиции подходим», рассказывает директор одной из подмосковных школ.

Учителя, которые сами приехали из Средней Азии или Закавказья, перекидываются парой слов с детьми мигрантов, что не только не мешает усвоению ими русского языка, но создает доброжелательную атмосферу в классе, «легитимизирует» инаковость, в том числе и лингвистическую. В некоторых подмосковных и московских школах в процесс адаптации недавно приехавшего из другой страны ученика школьная администрация и педагогический коллектив целенаправленно включают уже работающих в школе мигрантов - учителей, поваров, уборщиц.

Согласно наблюдениям учителей, зачастую дети мигрантов имеют иные поведенческие паттерны по сравнению с местными учениками. Как отмечают учителя, другой опыт и другие жизненные представления являются причинами иных форм поведения, проявляющихся не только в семье, но и в пространстве школы. Нередко поведенческие несоответствия служат основой для конфликтных ситуаций. В одной из 
московских школ на новогоднем балу кавказские старшеклассники демонстративно игнорировали бальные танцы: "... есть там небольшая группа чеченщев, дагестанцев, этнических азербайджанцев из Дагестана, которые отошли в сторону, ну, это вот следствие их культурного кода, и они не включались... Ну, соответственно к ним было сделано обращение в их сторону: "Что ж, вы, горныле друзья так выделяетесь?". Ну, им пошли навстречу, там где-то в середине прозвучала лезгинка...», - рассказывает учитель одной из московских школ.

Некоторым мигрантам свойственна перформативность в этническом поле. Публичное исполнение лезгинки в школе становится символичным маркированием пространства, реакцией на кавказофобскую городскую российскую среду. «Была школьная дискотека... И кавказиь стали танцевать лезгинку. Они это делали очень эффектно, очень красиво, очень здорово. В какой-то момент люди стали возмущаться. И мне кажется, это возмущение пошло именно от взросльх, а не от детей. Типа: "Что это такое, вы приехали сюда свои правила устанавливать». Потому что они раз станцевали, стали просить два, через какое-то время три,... в результате до драки не дошло, но чуть-чуть не дошло. Чуть-чуть», - рассказал преподаватель русского языка и литературы в старших классах московской школы.

Школьное пространство, как и городское, меняется под влиянием миграционных волн. Внеклассные практики становятся более разнообразными и зачастую этнически ориентированными. Местные школьники и учителя знакомятся с другой культурой, носителями которой являются дети мигрантов и/или их родители, они сталкиваются с новыми формами поведениями и жизненными стратегиями, что обогащает опыт всех участников образовательного процесса.

\section{ОБСУЖДЕНИЕ И ВЫВОДЫ}

Теория сегментированной ассимиляции выделяет несколько факторов, влияющих на адаптацию детей мигрантов. Согласно Портесу и Румбо [Portes, Rumbaut 2001] к ним относятся политика государства, которая может как препятствовать адаптации мигрантов, так и помогать их включению в принимающее общество. Второй фактор - это отношение принимающего общества к ребенку-мигранту. С одной стороны, для ребенка важно постоянно общение с представителями «местного» общества, это ведет к его более быстрой социализации в нем. Однако это же принимающее общество, в случае если оно настроено отрицательно по отношению к мигрантам или каким-то этническим меньшинствам, может препятствовать встраиванию в него ребенка-мигранта. И третьим фактором является отношение «своего», мигрантского сообщества к процессам адаптации детей в принимающем обществе, которое может как положительно влиять на них, так и препятствовать включению ребенка в принимающее общество.

Наше исследование показывает, что в процессе адаптации детей мигрантов в российских школах играют роль все упомянутые факторы. На уровне государства дети мигрантов выделяются администрацией школ при зачислении в школу как сложная социальная группа, присутствие которой в учебном заведении требует дополнительной 
нагрузки на учителей. Сегодня можно говорить о существовании в Москве и Подмосковье школ, в которых концентрируется большее число детей мигрантов, нежели в других учебных заведениях. Одни школы не хотят брать к себе детей мигрантов и отказывают им в приеме со ссылкой на переполненность. Как правило, это школы с высокими показателями ЕГЭ, в которые стараются отдать детей «местные», и часто они действительно заполняются раньше других. Другие школы, наоборот, записывают к себе всех детей вследствие недобора. Как правило, такие школы имеют низкие показатели ЕГЭ и в них чаще, чем в других школах района (города, округа), имеются специализированные классы (например, для детей-инвалидов до 2016 г., вечерняя школа и др.). Таким образом, на уровне школ происходит сегрегация, одни школы отбирают лучших, другие берут всех «остальных» [Константиновский и др. 2008; Шпаковская 2015].

Следует отметить, что такое явление как «мигрантская школа» требует дальнейшего рассмотрения и обоснования. В зависимости от позиции наблюдающего можно говорить не только о различном отношении к таким школам, но и оспаривать сам факт существования подобного маркирования. С одной стороны, как уже было отмечено, на уровне государственного дискурса категория детей мигрантов находится на периферии общественного внимания, и зачастую присутствие таких детей в учебном процессе игнорируется, что проявляется в фактическом отсутствии государственных программ для мигрантов. С позиции родителей «местных» детей можно говорить о существовании «плохих» школ, которые ассоциируются с высокой концентрацией в них мигрантов. На самом деле, сегодня определить количество школ, в которых число мигрантов действительно превышает число «местных», практически невозможно. Таким образом, в реальности можно говорить о наличии школ, в которых среднее число мигрантов составляет около 6-7 человек в классе, что уже является достаточным основанием для маркирования их как «мигрантских». А это, в свою очередь, может выступать в качестве отталкивающего фактора при выборе школы «местными».

Однако, попадая в эти «мигрантские» школы, дети оказываются в среде, которая готова их принять. На наш взгляд, успешная адаптация детей мигрантов в школах Москвы и Подмосковья связана с разнородностью первых. Это дети из разных стран, с разными историями, разными стилями жизни и семейными традициями. Ни в одной школе не было речи о каких-либо сообществах на этнической почве. Многие дети мигрантов, приезжая в Россию, говорят по-русски и практически сразу вливаются в школьный коллектив. Этничность играет роль лишь первое время, в особенности, когда дети плохо знают язык. Но, стоит ребенку встроится в коллектив класса, эти этнические границы стираются, в том числе и потому, что ребенок не встраивается в какие-то этнические сообщества.

Попадая в школы со «сложным социальным контекстом», дети мигрантов оказываются в социальной среде, которая сама является исключенной в российском обществе. Это дети из семей с низким социальным статусом, входящие в социально уязвимые группы. Дети мигрантов не чувствуют себя исключенными в школьном сообществе, так как они оказываются в социальной среде, предполагающей отклонения от нормы. Их история миграции вписывается в те сложные социальные истории, которые переживают их одноклассники. Фокус-группы, проведенные с детьми мигрантов и «местными» детьми, показали, что, если даже и не существует особой дружбы между ними, 
то в основном складывается нейтральное отношение к сверстнику как к «своему», к однокласснику. Дети мигрантов не входят в какие-то другие сообщества, кроме школьного, поэтому постепенно они полностью вливаются в коллектив, не имея другой альтернативы общения.

Важную роль во включении детей в принимающее общество играют их семьи. Мигранты из-за рубежа привозят детей только в том случае, если они уже встроены в местную жизнь и экономику страны. Это те мигранты, которые планируют жить в России и настроены на интеграцию своих детей в российское общество. Существующие в некоторых семьях рамки традиций, которые могут ограничивать детей в общении со сверстниками (в основном они касаются девочек-подростков), упоминались в интервью и фокус-группах, но ни разу не был приведен пример, когда ребёнок перестал бы ходить в школу или общаться со сверстниками вследствие каких-то запретов семьи. Учителя и дети указывают на то, что в основном семьи детей мигрантов нацелены на интеграцию детей, даже если внутри семьи они предпочитают придерживаться своих традиций, и родители при возможности помогают детям адаптироваться в принимающем обществе.

«Этнизация» школьного пространства является отражением и продолжением «этнизации» городской среды. Опасность заключается в том, что нередко как учителя, так и местные родители переносят свои негативные представления об интенсификации миграции в Москву и Подмосковье на школу. Они распространяют на детей мигрантов стереотипы, почерпнутые за стенами школы: из СМИ и собственного отрицательного опыта взаимодействия с мигрантами. Таким образом, можно говорить о двух «этнизациях» школьного пространства: о реальном усложнении этнической картины школ московского региона и актуализации этнического в образовательных практиках и об «этнизации» школьного пространства в оценочных представлениях взрослых, транслирующих свои взгляды детям.

\section{ЛИТЕРАТУРА}

Александров Д.А., В.В. Баранова, В.А. Иванюшина (2011). Дети из семей мигрантов в школах Санкт-Петербурга. Предварительные данные. СПб.: Издательство Политехнического университета. 100 с.

Александров Д.А., В.В. Баранова, В.А. Иванюшина (2012). Дети и родители-мигранты во взаимодействии с российской школой // Вопросы образования. 1: 176-199.

Александров Д.А., Иванюшина В.А., Казарцева Е.В. (2015) Этнический состав школ и миграционный статус школьников в России // Вопросы образования. 2: 173-195.

Деминцева Е.Б., В.М. Пешкова (2014). Мигранты из Средней Азии в Москве // Демоскоп Weekly. 597-598. URL: http://demoscope.ru/weekly/2014/0597/tema01.php (дата обращения: 10.06.2017).

Дятлов В.И., К.В. Григоричев (2014). Сибирь: динамика этнизации городского пространства переселенческого общества // Известия Иркутского государственного университета. 10: 8-19. 
Зайончковская Ж.А., Ю.Ф. Флоринская, К.А. Доронина, Д.А. Полетаев (2014). Мигранты глазами москвичей // Демоскоп Weekly. 605-606. URL:

http://demoscope.ru/weekly/2014/0605/tema01.php (дата обращения: 10.06.2017).

Константиновский Д.Л., В.С. Вахштайн, Д.Ю. Куракин (2008). «Бег с препятствиями». Кому доступно качественное общее образование? // Россия реформирующаяся. Ежегодник. 7. М.: Институт социологии РАН: 142-158.

Лярская Е.В. (2006). «У них же все не как у людей...»: Некоторые стереотипные представления педагогов Ямало-Ненецкого округа о тундровиках // Антропологический форум. 5: 242-258.

Омельченко Е.Л., Ю.В. Андреева, Е.Л. Лукьянова, Г.А. Сабирова, Г.А. Я.Н. Крупец (2010). Адаптация детей мигрантов в школе. Методическое пособие: рекомендации по проведению комплекса адаптационных мероприятий в общеобразовательных учебных заведениях РФ. Ульяновск: Издательство Ульяновского государственного университета. $216 \mathrm{c}$.

Пинская М.А., С.Г. Косарецкий, И.Д. Фрумин (2011). Школы, эффективно работающие в сложных социальных контекстах // Вопросы образования. 4: 148-177.

Сабирова Г.А., Ю.В. Андреева (2014). Школьная дружеская компания подростка с миграционной историей // Журнал социологии и социальной антропологии. 1: 170189.

Солдатова А. (2014). Опыт этнологического изучения школьных систем в полиэтничных мегаполисах (подходы и практики обучения детей этнических меньшинств в Москве, Лондоне и Мехико): дисс. ... канд. истор. наук. М.: Издательство Московского университета.

Троицкий К. (2017). Всеобщее право не для каждого. Доступ к школьному образованию для детей беженцев и трудовых мигрантов в России. Доклад комитета «Гражданское содействие». Москва. Май. URL: http://refugee.ru/wp-content/uploads/2017/05/Doklad-odostupe-k-obrazovaniyu.pdf (дата обращения: 10.06.2017).

Флоринская Ю.Ф., Н.В. Мкртчян, Т.М. Малева, М. Кириллова (2015). Миграция и рынок труда. М.: ИД "Дело". 108 с.

Фрумин И.Д., М.А. Пинская, С.Г. Косарецкий (2012). Социально-экономическое и территориальное неравенство учеников и школ// Народное образование. 1: 17-24.

Шпаковская Л.Л. (2015). Образовательные притязания родителей как механизм воспроизводства социальных неравенств // Журнал исследований социальной политики. 2: 211-224.

Ястребов Г.А., А.Р. Бессуднов, М.А. Пинская, С.Г. Косарецкий (2013). Проблема контекстуализации образовательных результатов: школы, социальный состав учащихся и уровень депривации территорий // Вопросы образования. 4: 188-246.

Ainsworth J. (2013). Sociology of education an A-to-Z guide. Thousand Oaks: SAGE Publications. $1056 \mathrm{p}$.

Alba R., J. Holdaway (2013). The children of immigrants in school: a comparative look at integration in the United States and Western Europe. NY: New York university press. 350 p.

Alba R., R. Silberman (2009). The children of immigrants and host-society education systems: Mexicans in the United States and North Africans in France // Teachers college record. 9: 1444-1475. 
Alba R., V. Nee (2003). Remaking the American mainstream: assimilation and the new immigration. Cambridge, MA: Harvard university press. 384 p.

Christensen G., P. Stanat (2007). Language policies and practices for helping immigrants and second-generation students succeed. The Transatlantic Task Force on immigration and integration. Washington DC: Migration policy institute. URL: http://www.migrationpolicy.org/pubs/ChristensenEducation091907.pdf. (дата обращения: 01.10.2017).

Crul M., H. Vermeulen (2003). The future of the second generation: the integration of migrant youth in six European countries. Special issue // International migration review. 37: 965-986.

Crul M., J. Holdaway (2009). Children of immigrants in schools in New York and Amsterdam: the factors shaping attainment // Teachers college record. 111(6): 1476-1507.

Crul M., J. Schneider, F. Lelie (2012). School careers of second-generation youth in Europe. Amsterdam: Amsterdam university press. 420 p.

Demintseva E. (2017). Labour migrants in post-soviet moscow: patterns of settlement // Journal of ethnic and migration studies. 43 (15): 2556-2572

Deyhle D. (1995). Navajo youth and anglo racism: cultural integrity and resistance // Harvard educational review. 65(3): 23-67.

Genesee F., K. Lindholm-Leary, W. Saunders, D. Christian (2006). Educating English language learners: a synthesis of the empirical evidence research. NY: Cambridge university press. 245 p.

Gibson M. (1998). Accommodation without assimilation: sikh immigrants in an American high school. Ithaca, NY: Cornell university press. 272 p.

Gil A., W.A. Vega, J.M. Dimas (1994). Acculturative stress and personal adjustment among Hispanic adolescent boys // Journal of community psychology. 22: 43-54.

Gordon M. (1964). Assimilation in American life: the role of race, religion, and national origins. NY: Oxford university press. $272 \mathrm{p}$.

James D.C. (1997). Coping with a new society: the unique psychosocial problems of immigrant youth // Journal of school health. 67: 98-102.

Karsten S. (2006). Policies for disadvantaged children under scrutiny: the dutch policy compared with policies in France, England, Flanders and the USA // Comparative education. 42 (2): 261-282.

Lacoste-Dujardin C. (1992). Yasmina et les autres de Nanterre et d'ailleurs : filles de parents maghrébins en France. Paris : Ed. De la Decouverte. 286 p.

Lapeyronnie D. (2008). Ghetto urbain. Ségrégation, violence, pauvreté en France aujourd'hui. Paris: Robert Laffont. 624 p.

Mehan H., L. Hubbard, I. Villanueva (1994). Forming academic identities: accommodation without assimilation among involuntary minorities // Anthropology and education quarterly. 25: 91-117.

OECD (2015). Immigrant students at school. Easing the journey towards integration. OECD publishing. URL: http://dx.doi.org/10.1787/9789264249509-en (дата обращения: 01.10.2017).

Olsen L. (1988). Crossing the schoolhouse border: immigrant students and the California public schools. SF: California tomorrow. 131 p. 
Portes A., M. Zhou (1993). The new second generation: segmented assimilation and its variants // The annals of the American academy of political and social science. 530: 74-96.

Portes A., R. Rumbaut (2001). Legacies: the story of the immigrant second generation. Berkeley, CA: University of California press and Russell sage foundation. 353 p.

Rogler L.H., D.E. Cortes, R.G. Malgady (1991). Acculturation and mental health status among Hispanics: convergence and new directions for research // American psychologist. 46: 585597.

Rumbaut R.G. (1994). The crucible within: ethnic identity, self-esteem, and segmented assimilation among children of immigrants // International migration review. 28: 748-794.

Rumbaut R.G. (1995). The new Californians: comparative research findings on the educational progress of immigrant children // California's Immigrant children: Theory, research, and implications for educational policy / R.G. Rumbaut, ed. San Diego: University of California. 17-70.

Rumbaut R.G. (1997). Assimilation and its discontents: between rhetoric and reality // International migration review. 31: 923-960.

Vernez G., A. Abrahamse A. (1996). How immigrants fare in U.S. education. Santa Monica, CA: RAND Corporation. $83 \mathrm{p}$. 


\title{
ADAPTATION OF MIGRANT CHILDREN IN THE SCHOOLS OF MOSCOW AND THE MOSCOW REGION
}

\author{
EKATERINA DEMINTSEVA, DARIA ZELENOVA, ELIZAVETA KOSMIDIS, \\ DMITRY OPARIN
}

\begin{abstract}
The paper presents the results of a study of the adaptation of migrant children in schools in Moscow and the Moscow region. We analyze the obstacles that migrant families face when enrolling a child in school and the situations they deal with in schools with a "socially challenging environment". We argue that in the eyes of teachers the ethnic origins of children are more important than their citizenship for defining what a "migrant student" is. Both the migrant children themselves and their teachers consider the students' low proficiency in Russian to be the key obstacle to their adaptation during their first year at school. The lack of classes of Russian as a foreign language, as well as of special training for teachers working in an ethnically diverse classroom also hamper assimilation. Given the significant inflows of migrant children, some schools are currently experiencing changes in the school environment. Extracurricular activities are becoming more diverse and often ethnically oriented. The enthnicization of the school environment is an extension of the ethnicization of the urban environment.
\end{abstract}

Key words: migrant children, schools, assimilation, adaptation, ethnization.

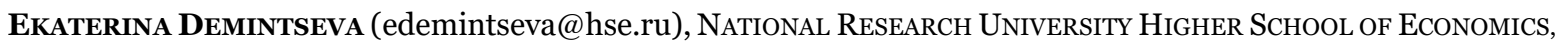
RUSSIA.

DARIA Zelenova (d.zelenova@gmail.com), NATIONAl ReSEARCh University Higher SchoOl Of Economics, RUSSIA.

ElizAVETA Kosmidis (kosmidislisa@gmail.com), NATIONAL RESEARCH UnIVERSiTy Higher SCHOOL OF ECONOMICS, RUSSIA.

DMITRY OPARIN (dimaoparin@hotmail.com), LoMONosov Moscow STATE UNIVERSITY, RusSiA.

THIS ARTICLE IS THE PRODUCT OF A RESEARCH PROJECT IMPLEMENTED AS PART OF THE BASIC RESEARCH PROGRAMME AT THE NATIONAL RESEARCH UNIVERSITY HigheR SCHOOL OF ECONOMICS (HSE) 2017.

DATE RECEIVED : JUNE 2017.

\section{REFERENCES}

Ainsworth J. (2013). Sociology of education an A-to-Z guide. Thousand Oaks: SAGE Publications. $1056 \mathrm{p}$.

Alba R., J. Holdaway (2013). The children of immigrants in school: a comparative look at integration in the United States and Western Europe. NY: New York university press. 350 p.

Alba R., R. Silberman (2009). The children of immigrants and host-society education systems: Mexicans in the United States and North Africans in France // Teachers college record. 9: 1444-1475.

Alba R., V. Nee (2003). Remaking the American mainstream: assimilation and the new immigration. Cambridge, MA: Harvard university press. 384 p.

Alexandrov D., Baranova V., Ivanyushina V. (2011). Deti iz semey migrantov v shkolakh SanktPeterburga. Predvaritel'nye dannye [Children from migrants' families in St. Petersburg schools. Preliminary data]. S-Petersburg: Izdatel'stvo Politekhnicheskogo universiteta. 100 p. 
Alexandrov D., Baranova V., Ivanyushina V. (2012). Deti i roditeli-migranty vo vzaimodeystvii s rossiyskoy shkoloy [Children and their migrant parents in cooperation with Russian school] // Issues of education. 1: 176-199.

Alexandrov D., V. Ivanyushina, E. Kazartseva (2015). Ethnic make-up of the schools and migratory status of the students in Russia // Issues of education. 2: 173-195.

Christensen G., P. Stanat (2007). Language policies and practices for helping immigrants and second-generation students succeed. The Transatlantic Task Force on immigration and integration. Washington DC: Migration policy institute. URL:

http://www.migrationpolicy.org/pubs/ChristensenEducation091907.pdf. (accessed: 01.10.2017).

Crul M., H. Vermeulen (2003). The future of the second generation: the integration of migrant youth in six European countries. Special issue // International migration review. 37: 965-986.

Crul M., J. Holdaway (2009). Children of immigrants in schools in New York and Amsterdam: the factors shaping attainment // Teachers college record. 111(6): 1476-1507.

Crul M., J. Schneider, F. Lelie (2012). School careers of second-generation youth in Europe. Amsterdam: Amsterdam university press. 420 p.

Demintseva E. (2017). Labour migrants in post-soviet moscow: patterns of settlement // Journal of ethnic and migration studies. 43 (15): 2556-2572

Demintseva E., V. Peshkova (2014). Migranty iz Sredney Azii v Moskve [Migrants from Central Asia in Moscow] // Demoscop Weekly [Demoscope Weekly]. 597-598. http://demoscope.ru/weekly/2014/0597/tema01.php (accessed: 10.06.2017).

Deyhle D. (1995). Navajo youth and anglo racism: cultural integrity and resistance // Harvard educational review. 65(3): 23-67.

Dyatlov V., K. Grigorichev (2014). Sibir': dinamika etnizatsii gorodskogo prostranstva pereselencheskogo obshchestva [Siberia: dynamic of the ethnization of the urban space of the settled society] // Izvestiya Irkutskogo gosudarstvennogo universiteta. 10: 8-19.

Florinskaya Yu., Mkrtchyan N., Maleva T., Kirillova M. (2015). Migratsiya i rynok truda [Migration and the labor market]. Moscow: ID "Delo". 108 p.

Frumin I., M. Pinskaya, S. Kosaretsky (2012). Sotsial'no-ekonomicheskoe i territorial'noe neravenstvo uchenikov i shkol [Socio-economic and territorial inequality of pupils and schools] // Narodnoe obrazovanie [Public education]. 1: 17-24.

Genesee F., K. Lindholm-Leary, W. Saunders, D. Christian (2006). Educating English language learners: a synthesis of the empirical evidence research. NY: Cambridge university press. 245 p.

Gibson M. (1998). Accommodation without assimilation: sikh immigrants in an American high school. Ithaca, NY: Cornell university press. 272 p.

Gil A., W.A. Vega, J.M. Dimas (1994). Acculturative stress and personal adjustment among Hispanic adolescent boys // Journal of community psychology. 22: 43-54.

Gordon M. (1964). Assimilation in American life: the role of race, religion, and national origins. NY: Oxford university press. $272 \mathrm{p}$.

James D.C. (1997). Coping with a new society: the unique psychosocial problems of immigrant youth // Journal of school health. 67: 98-102. 
Karsten S. (2006). Policies for disadvantaged children under scrutiny: the dutch policy compared with policies in France, England, Flanders and the USA // Comparative education. 42 (2): 261-282.

Konstantinovsky D., Vahstein V., Kurakin D. (2008). «Beg s prepyatstviyami». Komu dostupno kachestvennoe obshchee obrazovanie? ["Obstacle race". Who can afford good general education?] // Rossiya reformiruyushchayasya [Rossiya reformiruyushayasya]. Ezhegodnik [Annually]. 1. 7. Moscow: Institut sotsiologii RAN: 142-158.

Lacoste-Dujardin C. (1992). Yasmina et les autres de Nanterre et d'ailleurs : filles de parents maghrébins en France. Paris : Ed. De la Decouverte. 286 p.

Lapeyronnie D. (2008). Ghetto urbain. Ségrégation, violence, pauvreté en France aujourd'hui. Paris: Robert Laffont. 624 p.

Lyarskaya E. (2006). «U nikh zhe vse ne kak u lyudey...»: Nekotorye stereotipnye predstavleniya pedagogov Yamalo-Nenetskogo okruga o tundrovikakh ["They don't resemble people...". Some Yamal teachers' stereotypes about tundra nomads] // Antropologicheskiy forum [Antropological forum]. 5: 242-258.

Mehan H., L. Hubbard, I. Villanueva (1994). Forming academic identities: accommodation without assimilation among involuntary minorities // Anthropology and education quarterly. 25: 91-117.

OECD (2015). Immigrant students at school. Easing the journey towards integration. OECD publishing. URL: http://dx.doi.org/10.1787/9789264249509-en (accessed: : 01.10.2017).

Olsen L. (1988). Crossing the schoolhouse border: immigrant students and the California public schools. SF: California tomorrow. $131 \mathrm{p}$.

Omelchenko E.L., Yu.V. Andreeva, E.L. Lukyanova, Sabirova, G.A. Ya.N. Krupets (2010). Adaptatsiya detey migrantov v shkole. Metodicheskoe posobie: rekomendatsii po provedeniyu kompleksa adaptatsionnykh meropriyatiy $\mathrm{v}$ obshcheobrazovatel'nykh uchebnykh zavedeniyakh RF [Adaptation of migrants' children in school. The methodical manual: recommendations on carrying out of a complex of adaptive measures in educational institutions of the Russian Federation]. Ulyanovsk: Izdatel'stvo Ul'yanovskogo gosudarstvennogo universiteta. $216 \mathrm{p}$.

Pinskaya M., S. Kosaretsky, I. Frumin (2011). Shkoly, effektivno rabotayushchie v slozhnykh sotsial'nykh kontekstakh [Schools that work effectively in complex social contexts] // Voprosy obrazovaniya [Issues of education]. 4: 148-177.

Portes A., M. Zhou (1993). The new second generation: segmented assimilation and its variants // The annals of the American academy of political and social science. 530: 74-96.

Portes A., R. Rumbaut (2001). Legacies: the story of the immigrant second generation. Berkeley, CA: University of California press and Russell sage foundation. 353 p.

Rogler L.H., D.E. Cortes, R.G. Malgady (1991). Acculturation and mental health status among Hispanics: convergence and new directions for research // American psychologist. 46: 585597.

Rumbaut R.G. (1994). The crucible within: ethnic identity, self-esteem, and segmented assimilation among children of immigrants // International migration review. 28: 748-794.

Rumbaut R.G. (1995). The new Californians: comparative research findings on the educational progress of immigrant children // California's Immigrant children: Theory, research, and implications for educational policy / R.G. Rumbaut, ed. San Diego: University of California. $17-70$. 
Rumbaut R.G. (1997). Assimilation and its discontents: between rhetoric and reality // International migration review. 31: 923-960.

Sabirova G., Andreeva Yu. (2014). Shkol'naya druzheskaya kompaniya podrostka s migratsionnoy istoriey [School teenager company with a migration background] // Zhurnal sotsiologii i sotsial'noy antropologii [Journal of sociology and social anthropology]. 1: 170189.

Shpakovskaya L. (2015). Obrazovatel'nye prityazaniya roditeley kak mekhanizm vosproizvodstva sotsial'nykh neravenstv [Educational claims of parents as a mechanism for the reproduction of social inequalities] // Zhurnal issledovaniy sotsial'noy politiki [Journal of social policy studies]. 2: 211-224.

Soldatova A. (2014). Opyt etnologicheskogo izucheniya shkol'nykh sistem v polietnichnykh megapolisakh (podkhody i praktiki obucheniya detey etnicheskikh men'shinstv v Moskve, Londone i Mekhiko): diss. ... kand. istor. nauk [Experience in the ethnological study of school systems in polyethnic megacities (approaches and practices of teaching children of ethnic minorities in Moscow, London and Mexico). Thesis for the degree of candidate of historical sciences]. Moscow: Izdatel'stvo Moskovskogo universiteta.

Troitsky K. (2017). Vseobshchee pravo ne dlya kazhdogo. Dostup k shkol'nomu obrazovaniyu dlya detey bezhentsev i trudovykh migrantov v Rossii [Universal law is not for everyone. Access to school education for refugee and labour migrants' children in Russia]. Doklad komiteta «Grazhdanskoe sodeystvie» [Report of the Civic Assistance Committee]. Moscow. May. URL: http://refugee.ru/wp-content/uploads/2017/05/Doklad-o-dostupe-kobrazovaniyu.pdf (accessed: 10.06.2017).

Vernez G., A. Abrahamse A. (1996). How immigrants fare in U.S. education. Santa Monica, CA: RAND Corporation. 83 p.

Yastrebov G., A. Bessudnov, M. Pinskaya, S. Kosaretsky (2013). Problema kontekstualizatsii obrazovatel'nykh rezul'tatov: shkoly, sotsial'nyy sostav uchashchikhsya i uroven' deprivatsii territoriy [The problem of the contextualization of educational results: schools, the social make-up of students and the level of deprivation of territories] // Voprosy obrazovaniya [Issues of education]. 4: 188-246.

Zaionchkovskaya J., Y. Florinskaya, K. Doronina, D. Poletaev (2014). Migranty glazami moskvichey [Migrants through the eyes of the Moscovites] // Demoscop Weekly [Demoscope Weekly]. 605-606. http://demoscope.ru/weekly/2014/0605/tema01.php (accessed: 10.06.2017). 